\title{
KETERWAKILAN PEREMPUAN DALAM PARTAI POLITIK PERSPEKTIF SIYASAH SYAR'IYYAH
}

\author{
Benni Erick $^{(1)}$, Masyitah ${ }^{(2)}$ \\ ${ }^{1,2}$ Sekolah Tinggi Agama Islam Negeri Teungku Dirundeng Meulaboh \\ Email: bennierick@staindirundeng.ac.id
}

\begin{abstract}
ABSTRAK
Peran perempuan Indonesia saat ini dapat digambarkan sebagai manusia yang hidup dalam situasi dramatis. Disatu sisi perempuan Indonesia dituntut untuk berperan dalam semua sektor, disisi lain muncul tuntutan agar perempuan Indonesia tidak melupakan kodrat sebagai perempuan. Situasi dilematis yang dihadapi oleh para perempuan, dialami oleh perempuan Indonesia yang berkarir. Perempuan karir merasa terpanggil untuk mendarmabaktikan bakat dan keahlian bagi perkembangan bangsa dan negara. Disamping itu, perempuan sering di hantui oleh opini yang ada dalam masyarakat bahwa perempuan harus mengabdi pada keluarga. Dalam pandangan siyasah syar'iyyah tentang keterwakilan perempuan dalam partai politik dilihat dari kedudukan perempuan figh siyasah merupakan agenda tersendiri dan penting untuk dilihat. Persoalannya tidak sekedar mempertanyakan kembali boleh dan tidaknya perempuan menjadi imam (pemimpin), tetapi bagaimana konsepsi figh dalam memandang peran politik perempuan secara umum. Secara garis besar, dalam membicarakan keberadaan hak-hak kaum perempuan dalam berpolitik terdapat pendapat liberal-progresif yang membolehkan perempuan berpolitik dan secara konstektual dapat disimpulkan bahwa kaum perempuan juga berhak menjadi pemimpin sebagaimana kaum laki-laki. Kebijakan pemerintah tentang kuota perempuan dalam legislatif dilihat dari keterlibatan peran perempuan dalam ranah politik dan pemerintahan merupakan suatu anugerah bagi keberlanjutan suatu negara. Maka dapat dipastikan bahwasannya perempuan memiliki andil yang sanagt luar biasa dalam mengatur kehidupan berbangsa dan bernegara.
\end{abstract}

Kata Kunci: Keterwakilan Perempuan, Partai Politik, Siyasah Syar'iyyah

\section{ABSTRACT}

The role of Indonesian women today can be described as human being who live in dramatic situation. On the one hand, Indonesian women are required to have a role in all sectors, on the other hand there are demand that Indonesian women do not forget their nature as women. Dilemma situation faced by women, experienced by Indonesian women who have careers. Career women feel called to dedicate their talent and skill to the development of the nation and state. Aside from that, women are often feel haunted by existing opinion in society that women should dedicate to their family. In the view of siyasah syar'iyyah about women representation in political party, seen form the position of women fiqy siyasah are an agenda in itself and important to look at it. The problem was not asking whether or not women are allowed to become imam (leaders), but what is the concept of fiqh in looking at the political role of women in general. In general, discussing the existence of women's rights in politic, there is a progressive-liberal opinion that allow women to be involved in politics and it can be contextually determined that women are also entitled to be leaders of men. The government's 
Jurnal Sosial Humaniora Sigli (JSH)

p ISSN : 2615-3688

$e$ ISSN : 2716-0270

http://journal.unigha.ac.id/index.php/JSH

policy on women's quotas in the legislature, seen from the involvement of women's roles in politics and government, is a gift for the sustainability of a country. So, it can be ascertained that women have a very extraordinary share in regulating the life of the nation and state

Keywords : Women representation, Political party, Siyasah Syar'iyyah

\section{Pendahuluan}

Perempuan dan politik merupakan rangkaian dua kata yang dijadikan slogan oleh partai politik untuk mendongkrak elektabilitas pasrtai tersebut. Tatanan kehidupan umat manusia yang didominasi kaum laki-laki atas kaum perempuan sudah menjadi akar sejarah yang panjang. Di dalam tatanan itu perempuan ditempatkan sebagai the second human being (manusia kelas kedua) yang berada di bawah prioritas laki-laki yang membawa implikasi luas dalam kehidupan sosial di masyarakat.

Dalam konvensi internasional menetapkan hak setiap orang atas kebebasan berpikir, perpendapat, berkeyakinan, beragama dan perlindungan atas hak-hak tersebut (Pasal 18), hak setiap orang untuk berpendapat tanpa campur tangan dari pihak manapun dan hak atas kebebasan untuk menyatakan pendapat (Pasal 19), serta hak setiap warga negara untuk ikut serta dalam penyelenggaraan urusan publik (Pasal 25).

Kehadiran Islam sebagai penuntun, pembawa kabar gembira dan sekaligus pemberi peringatan bagi manusia, membuat pandangan terhadap perempuan berubah, harkat martabatnya pun naik, dan tindak kekerasan serta kesewenang-wenangan pun dihilangkan. Islam mendeklarasikan lakilaki dan perempuan senantiasa berkedudukan sama, Islam pun memberikan perempuan hak-hak syar'iy, hak-hak sipil, hak-hak kemanusiaan termasuk juga hakhak politik.

Dalam Islam kedudukan perempuan sama dengan kedudukan laki-laki, yang membedakan hanyalah amal shaleh mereka sesuai dengan disebutkan dalam al-Qur'an surah an-Nahl ayat 97 dan 98. Begitu pula kedudukan keduanya dalam politik, keduanya mempunyai hak yang sama yaitu mempunyai kebebasan untuk menduduki lembaga politik tentunya berdasarkan kemampuan yang mereka miliki.

Dalam konteks historis tentang peranan Islam dalam memperjuangkan tegaknya nilai-nilai hak asasi manusia, Islam sebagaimana agama-agama yang lain, juga menitik beratkan pada nilai persamaan derajat manusia disisi Tuhannya. Ketika berbicara tentang hak asasi manusia (huquuq al-Insaaniyyah), terdapat dua deklarasi yang menjadi perjuangan Nabi Muhammad saw, yaitu terkait dengan Piagam Madinah (Charter of Madina) dalam membangun masyarakat (ummah) di Madinah. Selain dari Piagam Madinah ada juga khutbah Haji Wada' yang didalamnya menegaskan hakhak perempuan, baik yang menyangkut harta, hak-hak dan perlindungan. Salah satu ajaran yang sangat urgen dalam Islam adalah pengakuan hak-hak perempuan (huququ al-Mar'ah) untuk diperlakukan secara bermartabat oleh komunitas manusia terutama kaum laki-laki, seperti yang diperjuangkan oleh Nabi Muhammad saw.

Dalam tujuan kehidupan bernegara untuk mencapai kesejahteraan bersama, maka pemerintah sudah sepatutnya memperhatikan hak dan kewajiban diantara sesama warga negara yang dilandasi oleh moral ukhuwah insaniyah. .

Profil perempuan Indonesia saat ini dapat digambarkan sebagai manusia yang hidup dalam situasi dilematis. Disatu sisi perempuan Indonesia dituntut untuk berperan dalam semua sektor, disisi lain muncul tuntutan agar perempuan Indonesia tidak melupakan kodratnya sebagai perempuan. Situasi dilematis yang dihadapi oleh para perempuan, dialami oleh perempuan Indonesia yang berkarier. Perempuan karier merasa terpanggil untuk mendarmabaktikan bakat dan keahliannya bagi perkembangan bangsa dan negara. 
Disamping itu, perempuan sering dihantui oleh opini yang ada dalam masyarakat bahwa perempuan harus mengabdi pada keluarga.

Di negara-negara berkembang, jumlah perempuan yang memiliki otoritas dalam struktur politik memang rendah dan tidak berimbang dengan jumlah laki-laki. Situasi seperti inilah yang disebut sebagai ketimpangan relasi gender dalam politik. Artinya, struktur politik yang didominasi laki-laki tersebut adalah artikulasi dari suatu hubungan kekuasaan antar gender yang sudah ada. Pembagian kerja dalam masyarakat yang berbasis pada gender telah membawa implikasi pada area publik dan area politik.

Persoalan mendasar yang dialami oleh kaum perempuan di Indonesia adalah kuatnya ketidakadilan gender yang menancap dalam struktur dan budaya masyarakat Indonesia. Munculnya kesenjangan-kesenjangan akses, hak dan peran perempuan dalam politik bila dibandingkan dengan kaum laki-laki, disebabkan karena minimnya kuantitas dan kualitas perempuan dalam jabatan publik yang dapat memperjuangkan kepentingan perempuan itu sendiri, maupun kepentingan masyarakat lainnya. Implikasi dari rendahnya keterwakilan perempuan dalam lembaga-lembaga penentu kebijakan publik, berakibat pada dikeluarkannya kebijakan publik yang timpang, karena kurang memperhitungkan kontribusi dan kebutuhan perempuan, serta menghasilkan kebijakan publik yang rendah kualitasnya. Masih sedikit perempuan yang menduduki jabatan publik dan mampu berperan aktif dalam kehidupan politik.

\section{Pembahasan}

\section{Perempuan dan Politik}

Perempuan dan politik merupakan rangkaian dua kata yang dijadikan slogan oleh partai politik atau institusi politik lainnya. Tatanan kehidupan umat manusia yang di dominasi kaum laki-laki atas kaum perempuan sudah menjadi akar sejarah yang panjang, peran perempuan dalam ruang publik dianggap masih terlalu rendah, sehingga marginalisasi gender masih menjadi menjadi permasalahan dalama tatanan sosial masyarakat saat ini. Dalam tatanan itu perempuan ditempatkan sebagai the second human being (manusia kelas kedua) yang berada di bawah prioritas lakilaki yang membawa implikasi luas dalam kehidupan sosial di masyarakat.

Penelitian di Amerika (Stanley,1990) menunjukkan bahwa telah terjadi suatu gelombang perubahan yang cukup besar. Makna perempuan mulai berubah yang tampak dengan banyaknya perempuan yang masuk dalam dunia politik. Sejak saat itu terbentuk suatu pandangan baru tentang perempuan yang mengukuhkan citra bahwa ternyata perempuan layak memasuki dunia politik yang selama ini didominasi laki-laki. Fenomena peran perempuan dalam ranah publik termasuk politik khususnya dalam posisi sebagai pemimpin digambarkan Stanley (1990) sebagai fenomena yang sama terjadi di beberapa negara. Ternyata dapat diidentifikasi bahwa perempuan di ranah publik menunjukkan kinerja dan pencapaian karir yang lebih bagus dibanding laki-laki terutama jika dilihat dari karakteristik personal perempuan.

Pandangan tersebut mengartikan bahwa dunia politik memberi ruang bagi adanya keseteraan gender. Bahwa keseteraan jender menuntut kaum perempuan sebagai agent of change (Moser, 1993), yang berpotensi besar bagi terjadinya perubahan. Karena itu peran perempuan sebagai pemimpin (dalam arti luas) harus dimulai dari pemberdayaan diri kemudian dengan pemerataan kekuasaan dan pemberian tanggungjawab dan otonomi. Selanjutnya Naomi menyebutkan bahwa kekuasaan mendasar yang dibutuhkan untuk dapat meningkatkan posisi tawar menawar harus didukung dengan uang, kesempatan, kesehatan, pendidikan dan keterwakilan politis. 
Dari uraian tersebut dapat disimpulkan bahwa keterlibatan perempuan dalam politik membawa dampak positif baik bagi perempuan itu sendiri maupun untuk lingkungan sekitarnya. Sejalan dengan itu, hasil penelitian Bank Dunia (dalam Sutinah, 2006) membuktikan bahwa keterkaitan antara jumlah perempuan dalam kehidupan politik akan memberikan dampak positif pada penurunan tingkat korupsi.

Keterlibatan perempuan dalam politik pada kenyataannya tidak dapat terjadi dengan mudah. Karena di dalam interaksi sosial perempuan dan laki-laki memerlukan pemahaman secara mendalam tentang konsep patriarki. Patriarki pada dasarnya memiliki 2 (dua) konsep, yaitu sebagai 'ideologi' dan sebagai 'sistem'. Sebagai ideologi, patriarki dapat didefinisikan secara ringkas sebagai "kekuasaan laki-laki, hubungan sosial dengan mana laki-laki menguasai" (Bhasin, 1996). Sementara itu, secara luas patriarki dapat definisikan sebagai "a system of interrelated structures through which men exploit women" (Walby, 1990), Suatu struktur sosial yang saling berhubungan dan di dalamnya laki-laki mengeksploitasi perempuan. Patriarki, sebagai suatu ideologi, menyatu dalam budaya manusia. Aturan-aturan yang mengatur antara laki-laki dan perempuan tersebut dapat mengambil bentuk yang berbeda-beda dalam setiap masyarakat.

Perempuan masih dianggap bukan makhluk penting melainkan sekedar pelengkap yang diciptakan dan untuk kepentingan laki-laki. Sulit bagi perempuan untuk melangkah ke ranah kekuasaan selama gagasan tentang kekuasaan selalu diidentikkan dengan maskulinitas. Oleh karena itu agar perempuan merasa nyaman dan langgeng dalam dunia kekuasaan mereka tidak harus mengubah jati diri menjadi maskulin, yang harus berubah dan diubah adalah pola pikir atas kekuasan itu sendiri. Sudah saatnya perpekstif manusia atas kekuasaan yang selama ini dianggap sarat dengan kesan maskulin harus di rubah dengan kepentingan-kepentingan yang dapat menampung aspirasi dan kebutuhan kaum perempuan.

Suatu konsep mengenai kekuasaan perempuan yang berbeda dengan kekuasaan laki-laki yang selama ini menjadi acuan semua pihak. Kekuasaan dalam konsep feminisme adalah kekuasaan yang penuh dilimpahi kasih sayang. Kekuasaan semacam ini tidak berpusat pada diri sendiri melainkan lebih diarahkan untuk mencapai suatu tujuan. Selain itu kekuasaan perempuan juga mencakup gagasan memberdayakan orang lain.

Perempuan dan politik sering digunakan slogan untuk kampanye agar perempuan tertarik menyumbangkan suaranya pada partai politik. Akan tetapi itu hanya sebagai sebatas slogan karena saat pemilu berakhir partai politik lupa akan janjinya. Kepentingan perempuan saat kampanye dijanjikan akan dijadikan sebagai agenda politik tidak pernah di realisasikan. Kalaupun diikutsertakan namanya ditempatkan pada urutan bawah atau yang dikenal dengan nomer sepatu. Berbagai alasan dikemukakan oleh para pemimpin partai perihal penurunan keterwakilan perempuan di DPR.

Kendala pertama yang dihadapi partai politik yaitu kesulitan dalam merekrut anggota legislatif perempuan. Persoalan terkadang tidak hanya pada kuantitas tetapi juga kualitas calon. Dengan Alasan minimnya kader perempuan terkait dengan sistem pengkaderan partai yang memang kurang memberi tempat, perhatian, serta peluang pada perempuan. Kedua, partai politik mengaku sulit mengajak perempuan terlibat dalam wacana politik, karena rendahnya kesadaran atas pendidikan politik yang diterima masyarakat awam terutama kaum perempuan. Selain kendala- kendala tersebut perempuan juga terhambat karena modal. Karena untuk bisa masuk pada lembaga-lembaga politik formal seseorang 
harus memiliki sumber daya ekonomi yang mendukung atas pencalonan diri untuk dapat maju sebagai calon wakil rakyat pada parlemen (modal).

Perempuan pada setiap tingkat sosial politik sering merasa dirinya kurang terwakili dalam parlemen dan jauh dari keterlibatan dalam pembuatan keputusan. Perempuan yang ingin masuk dalam dunia politik secara kenyataan bahwa politik dan budaya sering berseberangan. Perempuan dan politik sering mengalami pasang surut yang berakhir pada penyempurnaan, partisipasi perempuan dalam pembangunan terutama dalam pengambilan keputusan dan menduduki posisi strategis sangat rendah, baik di bidang eksekutif, legislative yudikatif maupun lembaga lainnya.

Perempuan dan politik merupakan dua hal yang sulit dibayangkan terutama pada negara-negara berkembang. Hal ini disebabkan telah dibentuk oleh budayanya masing- masing yang menekankan bahwa kedudukan atau peranan wanita berkisar hanya dalam lingkungan keluarga saja, sedangkan politik yang digambarkan adalah sebagai sesuatu yang berkenaan dengan kekuasaan. Akan tetapi kedudukan perempuan yang demikian ternyata tidak dapat dipertahankan karena dengan berkembangnya ilmu pengetahuan dan teknologi pola pikir masyarakat juga terus berkembang, sehingga stigma negatif masyarakat tentang keterlibatan perempuan dalam politik perlahan mulai mendapat tempat serta dapat menaikkan derajatnya diberbagai bidang termasuk politik.

Memang masih terdapat hambatan yang besar untuk menembus pandangan bahwa politik hanya milik laki-laki, tetapi kini masyarakat mulai membuka diri dan menyadari bahwa perempuan dapat terjun dan terlibat dalam politik asalkan diberi kesempatan, seiring dengan kemajuan teknologi dan terbukanya pola pikir masyarakat hal ini terjadi baik di dunia Barat maupun di dunia Timur. Sekarang ini hampir semua negara telah memberikan dan melibat kaum perempuan atas hak politiknya, hal ini diperetgas oleh upaya PBB bagi proses perkembangan kedudukan perempuan dalam ranag politik.

Usaha PBB dalam mempebaiki kedudukan perempuan adalah membentuk badan The United Nations Committee on the Status of Women. Dalam sidangnya yang pertama pada tanggal 11 Desember 1948, PBB memperingati pada anggotanya agar membentuk undang-undang yang menjamin persamaan hak antara laki-laki dan perempuan. Keterlibatan perempuan Indonesia dalam politik sebenarnya bukan lagi merupakan hal yang baru, banyak kaum perempuan Indonesia yang terlibat dan ambil bagian bersama kaum laki-laki dalam upaya mencapai kepentingan berbangsa, perempuan Indonesia banyak yang terlibat dalam upaya kemerdekaan Indonesia, sehingga tidak sedikit pahlawan nasional lahir dari kaum perempuan. Begitupun pada era modern saat ini, perempuan telah banyak mengambil peran dan menjalankan fungsinya dalam ruang publik, sehingga seiring dengan perkembangan jaman pola pikir perempuan akan kemajuan tidak lagi menjadi hal yang tertinggal, karena mereka telah turut serta secara aktif dalam pergerakan sosial, budaya, agama, ekonomi, politik serta kebangsaan.

\section{Kuota Perempuan Dalam Legislatif}

Selama lebih dari 60 tahun terakhir, Republik Indonesia telah melalui proses transformasi yang mendasar diberbagai aspek kehidupan termasuk politik. Menyatakan kemerdekaan pada Tahun 1945. Indonesia langsung memberikan hak politik yang setara antara laki-laki dan perempuan, perempuan di Indonesia mulai berhak menggunakan hak pilih pada tahun 1945, meskipun pemilu perdana baru digelar pada Tahun 1955.

Salah satu lembaga politik yang menjadi ukuran demokrasi adalah partai politik (parpol). Parpol menjadi lembaga politik yang jauh lebih dinamis 
dibandingkan dengan lembaga formal lainnya karena di dalam parpol mengemban misi berbagai fungsi politik. Parpol sebagai salah satu indikator berjalannya mesin demokrasi tentunya tidak diskriminatif dalam merekrut atau mengkader anggotaanggotanya terutama secara gender. Namun demikian, masih terdapat partai tertentu yang mengadopsi nilai-nilai patriarki sehingga akses perempuan sangat terbatas. Diskriminasi yang bersumber pada nilainilai patriarki bila dibiarkan akan semakin memperkecil akses politik perempuan ke dalam parpol. Sebagai akibatnya keterwakilan perempuan dalam DPR pun akan semakin mengecil pula.

Di Indonesia partisipasi politik perempuan dilakukan dengan prinsip pemberian kuota. Partisipasi politik perempuan dalam council mendapatkan kuota 30 persen yang menjadikan peran partai sangatlah penting. Namun demikian, kuota tersebut masih belum menunjukkan realitas keterwakilan perempuan yang sebenarnya mengingat jumlah perempuan lebih banyak daripada laki-laki. Sebagai upaya mewujudkan beberapa ketercapaian prestasi perempuan dalam politik, maka hal pertama yang harus dilakukan perempuan adalah berperan aktif dalam parpol. Peran politik tersebut menunjukkan fungsi yang dijalankan parpol, misalnya fungsi artikulasi kepentingan, pendidikan politik, komunikasi politik, sosialisasi politik dan rekrutmen politik. Oleh karena itu dunia parpol merupakan institusi politik yang paling dinamis dibandingkan dengan lembagalembaga formal lainnya (Windyastuti, 2004) yang di dalamnya perempuan mendapatkan haknya.

Dengan lolosnya UU No. 12 Tahun 2003 tentang Pemilihan Umum menjadi entry point bagi perempuan untuk dapat lebih banyak berkiprah dalam dunia politik melalui parpol. Pencantuman secara tegas kuota 30 persen untuk perempuan sebagaimana tertera dalam pasal 65 ayat (1) adalah sebagai bentuk affirmative action yang berlaku dalam jangka waktu tertentu. Dalam pasal tersebut, paling tidak telah mengikat parpol dengan memberikan nominasi 30 persen kepada perempuan ke dalam daftar calon legislatif (caleg). Menurut Ani Sucipto (Kompas, 24 Februari 2003) ketentuan pasal 65 ayat (1) tersebut membawa beberapa implikasi bagi parpol dan perempuan, yaitu:

1) Perempuan mulai di tingkat kecamatan, kabupaten, provinsi hingga pusat harus bekerja keras mempersiapkan diri menjadi caleg yang dapat dicalonkan bagi parpol yang bersangkutan. Oleh sebab itu perlu dipersiapkan bank data perempuan potensial yang mampu dan mau dinominasikan sebagai caleg;

2) Semua parpol perlu segera menyusun landasan politik, termasuk berbagai pandangan dan program mereka mengenai kesetaraan dan keadilan gender;

3) Parpol menyiapkan kader perempuan yang bisa dinominasikan;

4) Pemberlakuan tindakan afirmatif untuk perempuan ke dalam kepengurusan parpol di berbagai tingkatan;

5) Perempuan terus menerus membentuk jaringan dengan laki-laki di parpol, LSM, media massa, pemerintahan dan akademisi untuk memperjuangkan proses nominasi caleg.

Kebijakan tersebut ternyata dalam prakteknya tidak diakomodir secara sempurna oleh semua parpol. Walaupun beberapa parpol sudah menyerahkan mekanisme dalam kepengurusan, namun platform parpol untuk kaderisasi ataupun kepengurusan tidak pernah mensyaratkan adanya keharusan merekrut pengurus perempuan (misalnya sebagai salah satu ketua). Kalaupun ada dalam kepengurusan, perempuan lebih banyak menjadi bendahara yang merupakan stereotype sebagai 
Jurnal Sosial Humaniora Sigli (JSH)

p ISSN : 2615-3688

$e$ ISSN : 2716-0270

http://journal.unigha.ac.id/index.php/JSH

pekerjaan

perempuan.

(www.pikiranrakyat.com).

Permasalahan mendasar dalam pembahasan ini adalah apakah dengan adanya keterwakilan perempuan maka otomatis sekaligus juga menciptakan perubahan kebijakan publik yang dapat menjawab persoalan perempuan? Meskipun perempuan telah disediakan kuota keterwakilan 30 persen tetapi ternyata belum diikuti dengan perubahan kultur, perubahan paradigma, dan dominasi budaya patriarki sedemikian rupa sehingga tidak mudah mengubah pandangan bahwa politik adalah wilayah publik yang dapat dimasuki perempuan. Jumlah perempuan di bidang politik lebih sedikit daripada potensi yang ada untuk mampu berkompetisi dengan para pria yang selama ini memiliki konstruksi sosial (dianggap) lebih maju daripada perempuan. Realitas ini akan membentuk ukuran council yang kecil (Muttalib \& Khan, 1982).

Fenomena kualitas perempuan di DPRD perlu dipertanyakan, karena proses pemilihan mereka menjadi anggota DPRD diawali dari keterlibatannya dalam sebuah parpol. Dinamika parpol sangat fluktuatif dan penuh dengan "perjudian" (gambling), sementara di luar parpol terdapat banyak perempuan berkualitas dan telah mapan berada pada posisi strategis di berbagai bidang. Menjadi pengurus parpol atau anggota dewan bukanlah sesuatu yang menarik buat perempuan apalagi jika hanya dijadikan sekadar sebagai alat memenuhi kuota dan bukan untuk pertimbangan kualitas, kemampuan dan wawasannya. Selain itu ada pesimisme dan sinisme masyarakat berkaitan dengan kehidupan dan peran parpol.

Selama ini rekrutmen kader parpol belum memiliki pola yang baik dan berkelanjutan. Hal ini mengakibatkan terbatasnya kader perempuan dengan kualitas memadai untuk mendukung kemampuan partai dalam memenangkan pemilu. Keberadaan perempuan digunakan parpol cenderung hanya sebagai pendulang suara sedemikian rupa sehingga perekrutan perempuan untuk partai bukan dilihat dan ukuran kualitasnya namun lebih berdasar figur dan popularitasnya di masyarakat.

Karena itu diperlukan berbagai langkah kreatif, strategis, dan persuasif dari lembaga masyarakat, pemerintahan dan semua parpol untuk mendorong dan mencerdaskan perempuan. Parpol dan lembaga masyarakat, misalnya, harus dapat menyempurnakan pola rekrutmen kader perempuannya secara lebih sistematis dan berkelanjutan, melakukan advokasi, serta mengembangkan program-program pelatihan dan pendidikan politik yang dibutuhkan perempuan. Langkah ini dilakukan bukanlah sekadar karena keterpaksaan memenuhi ketentuan UU, tetapi atas didasar oleh kesadaran politik untuk memberikan ruang yang lebih luas bagi perempuan dalam mengaktualisasikan hak-haknya. Kebijakan yang menjamin hal ini harus segera diterbitkan dan kemudian disosialisasikan pemerintah kepada seluruh masyarakat mulai dari tingkat pusat hingga daerah di setiap kabupaten/kota hingga ke masyarakat yang jauh dan terpencil. Langkah informatif ini diperlukan sekaligus untuk menyamakan persepsi dan menyatukan langkah dalam menghapus stigma atau pandangan negatif tentang perempuan.

Ketika perempuan bertanggungjawab penuh atas nasib kaum yang diwakili, seiring dengan itu muncul persoalan kualitas kerjanya. Kualitas kerja perempuan terwujud dalam setiap idenya. Dalam menghadapi berbagai persoalan, perempuan harus menunjukkan diri dengan citra penuh inisiatif, mampu sebagai penggerak (motivator) bagi perempuan lain atau bahkan bagi laki-laki anggota legislatif lainnya. Meskipun minoritas, bukan berarti kalah dalam kualitas. Dengan jumlah atau kuota yang kecil, perempuan seharusnya justru mampu menyuarakan kepentingan masyarakat dengan lantang. Dengan 
"kelembutan"nya, memungkinkan perempuan mampu menjadi kekuatan besar dalam menyelesaikan berbagai persoalan. Kecil dalam jumlah namun besar dalam prestasi, maka partisipasi perempuan makin siginifikan, berbobot, dan dihargai sedemikian rupa sehingga berpeluang dalam mempengaruhi proses penyusunan kebijakan mengatasi baik isu-isu lokal maupun nasional.

Faktor tanggung jawab dan kualitas menjadi sebuah "paket" penting yang mampu menggambarkan keterwakilan perempuan secara ideal. Ketika kualitas sudah tercapai, maka selanjutnya perlu pula dilihat faktor pertimbangan perencanaan dan administrasi. Perempuan di legislatif adalah pihak yang mewakili masyarakat. Dengan posisinya sebagai anggota legislatif yang memiliki hak bersuara, perempuan membawa misi menyuarakan kepentingan masyarakat yang memilihnya. Perempuan yang terpilih berkewajiban melayani masyarakat dalam berbagai bentuk kegiatan berupa bekerja dengan baik, mampu melakukan perencanaan, mengelola, melakukan pengawasan, dan berkoordinasi.

Dalam bukunya yang berjudul "The Politic of Reprecen”, Anne Phillips (1995) menjabarkan teori politik kehadiran yang menyebutkan bahwa politisi perempuan memiliki kelengkapan terbaik untuk mewakili kepentingan kaumnya. Teori ini memprediksi bahwa ada kaitan yang sangat erat antara representasi deskriptif dan representasi substantif. Dengan kata lain, keterwakilan secara deskriptif (jumlah perempuan di parlemen) meningkat, maka kepentingan perempuan pun akan semakin digaungkan di parlemen. Pendapat Phillips ini didasari oleh perbedaan laki-laki dan perempuan dalam kehidupan sehari-hari. Perbedaan ini meliputi pola pengasuhan anak, pendidikan dan pekerjaan, jenis pekerjaan di dunia kerja, paparan kekerasan terhadap perempuan, dan kejahatan seksual yang dialami oleh perempuan. Namun pada akhirnya, Phillips tetap tidak bisa memastikan apakah jumlah yang lebih banyak di parlemen akan mengubah agenda politik untuk lebih mengarusutamakan kepentingan perempuan.

Upaya- upaya yang dapat dilakukan untuk memenuhi jumlah kandidat perempuan minimal 30\% dan tercapainya jumlah keterwakilan perempuan yang signifikan dilembaga legislatif yaitu yang pertama meningkatkan pemahaman dan kesadaran politik kaum perempuan sehingga semakin bertambah minat mereka untuk terjun di dunia politik, Kedua meyakinkan partai politik bahwa peran serta perempuan dalam pengambilan kebijakan publik sangat penting sehingga perlu meningkatkan rekrutmen calon perempuan dan menempatkan mereka dalam daftar calon tetap (DCT) partai politik. Ketiga meyakinkan masyarakat termasuk media massa agar mendukung keterwakilan perempuan pada lembaga legislatif khususnya lembaga-lembaga legislatif daerah.

Perjuangan untuk memenuhi kuota $30 \%$ ini memang bukan hal yang mudah terutama jika menyadari bahwa budaya patriarki sudah sedemikian merasuk dalam kehidupan berbangsa dan bernegara. Akan tetapi perlu dipikirkan juga sesungguhnya dibutuhkan bukan hanya sekadar memenuhi kuota tersebut melainkan bagaimana mempersiapkan landasan kerja yang dapat memfasilitasi perempuan untuk masuk ke arena politik sehingga yang dipersiapkan adalah kualitas.

Dengan begitu di masa depan tidak ada lagi ditemukan wakil- wakil perempuan di parlemen yang menjadi hiasan belaka. Karena yang dibutuhkan bukan hanya perempuan dalam arti fisik jasmani melainkan perempuan yang memiliki komitmen pada upaya-upaya pemberdayaan perempuan dan perempuan yang dapat mengartikulasikan kepentingan strategi 
perempuan menuju terciptanya kesetaraan dan keadilan gender dalam seluruh aspek kehidupan baik dalam ruang lingkup keluarga, masyarakat dan negara.

\section{Perempuan dan politik Dalam Perspektif Siyasah Syar'iyyah}

Keterwakilan perempuan dalam partai politik tidak hanya memilih anggota yang mampu memenuhi persyaratan sebagai anggota politik namum harus memiliki keberanian dan kapasitas, baik itu pengetahuan maupun keterampilan yang nantinya dapat bermanfaat bagi masyarakat, berupa program-program yang mampu menjawab atas kebutuhan-kebutuhan strategis, sehingga bukan hanya dijadikan sebagai pelengkap ataupun sebagai penggugur kewajiban dalam keterwakilan perempuan, tetapi juga sebagai penggerak dan perancang suatu program untuk menggerakan kaum perempuan dalam rangka mendukung setiap tahapan pembangunan.

Siyasah syar'iyyah adalah bagian dari siyasah syar'iyyah (politik hukum Islam) atau lebih populer dengan istilah Ilmu Tata Negara. Siyasah syar'iyyah merupakan pemaham politik dan perspektif keislaman yang universal. Untuk memperoleh pemahaman yang tepat tentang siyasah syar'iyyah, maka perlu dijelaskan pengertian masing-masing kata secara etimologi (bahasa) siyasah syar'iyyah adalah keterangan tentang pengertian atau paham dari maksud ucapan pembicaraan, atau pemahaman yang mendalam terhadap maksud perkataan dan perbuatan. Maka kata siyasah syar'iyyah secara leksikal berarti penegetahuan, paham, dan mengerti, istilah ini dipakai secara khusus dalam bidang hukum agama, yurisprudensi Islam. Sementara secara termologi kata siyasah syar'iyyah di pahami bahwa pemahaman yang mendalam, yang membutuhkan pengerahan potensi akal.
Sementara kata, "siyasa" berasal dari kata sasa, memiliki banyak makna yaitu mengemudi, mengendali, pengendali, cara pengendalian. Kata ini dalam kamus almunjid dan Lisan al-Arabi berarti mengatur, mengurus, dan memerintah. Jadi, siyasah menurut bahasa mengandung beberapa arti, yaitu mengatur, mengurus, memerintah. Jadi siyasah menurut bahasa mengandung beberapaarti, yaitu mengatur, mengurus, memerintah, memimpin, membuat, membuat kebijaksanaan, pemerintahan dan politik, artinya mengatur, mengurus dan membuat kebijaksanaan atas sesuatu yang bersifat politis untuk mencapai suatu tujuan.

Adapun secara terminologi yang dimaksud dengan siyasah adalah mengatur atau memimpin sesuatu dengan cara yang membawa kepada kemashlahatan. "Undangundang letakkan sebagai dasar untuk memelihara ketertiban dan kemashlahatan serta mengatur keadaan. "Definisi-definisi tersebut menegaskan bahwa wewenang membuat segala bentuk hukum, peraturan, dan kebijaksanaan yang berkaitan dengan pengaturan kepentingan negara dan urusan umat guna mewujudkan kemashlahatan umum terletak pada pemegang kekuasaan (pemerintah, uli al-'amr atau wulat al-'amr). Karena itu, segala bentuk hukum, peraturan, dan kebijaksanaan yang dibuat oleh pemegang kekuasaan bersifat mengikat. Ia wajib ditaati oleh mayarakat selama semua produk itu secara subtansial tidak bertentangan dengan makna syari'ah.

Pembagian bidang-bidang siyasah syar'iyyah tidak selayang dipandang sebagai "pembidangan yang telah selesai". Pembidangan siyasah syar'iyyah telah, sedang, dan akan berubah sesuai dengan pola hubungan antar manusia serta bidang kehidupan manusia yang membutuhkan pengaturan secara siyasah. Bila dikaji lebih jauh, tujuan untuk menciptakan good governance lebih banyak terkonsentrasi pada fiqh dusturi. Oleh karena itu, pada 
dasarnya, good governance dapat dikelompokkan kedalam bidang kajian siyasah syar'iyyah, karena menyangkut administrasi, tata kelola, dan penyelanggaraan suatu negara.

Politik pada hakekatnya adalah kekuasaan (power) dan pengambilan keputusan. Lingkupnya dimulai dari institusi keluarga hingga institusi politik formal tertinggi. Oleh karena itu pengertian politik pada prinsipnya meliputi masalah-masalah pokok dalam kehidupan sehari-hari yang pada kenyataannya selalu melibatkan perempuan. Keterlibatan perempuan dalam politik bukanlah dimaksudkan untuk menjatuhkan, menurunkan, atau merebut kekuasaan dari laki-laki, melainkan dimaksudkan agar bisa menjadi mitra sejajar laki-laki.

Kedudukan perempuan dalam siyasah syar'iyyah merupakan agenda tersendiri dan penting untuk dilihat. Persoalannya tidak sekedar mempertanyakan kembali boleh dan tidaknya perempuan menjadi imam (pemimpin), tetapi bagaimana konsepsi siyasah syar'iyyah dalam memandang peran politik perempuan secara umum. Secara garis besar, dalam membicarakan keberadaan hak-hak kaum perempuan berpolitik terdapat pendapat liberal-progresif yang membolehkannya perempuan berpolitik.

Pendapat liberal-progresif adalah yang menyatakan bahwa Islam sejak awal telah memperkenalkan konsep keterlibatan perempuan dalam peran politik. Secara eksplisit kelompok ini mengatakan bahwa perempuan mempunyai hak pilih dalam berpolitik. Mereka juga diizinkan memangku tugas-tugas politik seberat yang dipangku oleh laki-laki. Kaum ulama dari golongan dari kelompok Khawarij dan Musyabbihah menggunakan dalil-dalil alQuran tentang konsep adalah (keadilan) dan musawah (persamaan) yang selalu dijunjung tinggi dalam Islam, dan juga sebagai organisasi Islam terbesar di indonesia, Nahdlatul ulama (NU) tidak saja selalu menghiasi wacana publik Indonesia, tetapi juga menjadi inspirasi bagi gerakan dan pemikiran keislaman yang berwawasan kebangsaan, respon terhadap perubahan dan akomodatif terhadap kebudayaan lokal nusantara.

NU selalu memposisikan diri sebagai jangkar nusantara, terutama yang digalang oleh kader-kader mudanya. Mereka mempunyai gagasan keagamaan progresif dalam merespon modernitas dengan menggunakan basis pengetahuan tradisional yang mereka miliki setelah di persentuhkan dengan pengetahuan baru dari berbagai khazanah modern. Mereka tidak hanya peduli dengan modernitas yang terus di kritik dan disikapi secara hati-hati, tetapi juga melakukan revitalisasi tradisi.

Dalam konteks ini, NU menjadikan kepercayaan teologis sebagai basis pengembangan masyarakat dengan mengusung isu-isu universal seperti, HAM, demokrasi, civil society termasuk juga kesetaraan gender, dengan munculnya calon-calon ulama perempuan di Indonesia ini sebagai salah satu indikator awal akan terbebasnya perempuan dari belenggu penindasan dan ketidakadilan. Pengertian ulama sebagai penerus Nabi (al-ulamau waratsatul ambiya) tidak hanya tertentu bagi kaum laki-laki. Perempaun yang seringkali hanya ditempatkan di dalam rumah, sudah saatnya tampil ke ruang publik untuk mengayomi seluruh umat, baik laki-laki maupun perempuan.

Berkaitan dengan posisi perempuan dalam memperoleh hak-hak politik, Islam mengakui pentingnya peran kaum perempuan dalam kehidupan masyarakat dan dampaknya dalam kehidupaun politik. Oleh karena itu kaum perempuan telah diberikan hak-hak politik yang mencerminkan status mereka yang bermartabat, terhormat dan mulia dalam Islam.

Perjuangan perempuan adalah salah satu upaya mewujudkan demokratisasi karena dengan adanya kesetaraan gender 
maka seluruh masyarakat baik laki-laki maupun perempuan mempunyai akses untuk melakukan proses demokratisasi itu sendiri. Sebelum terwujud kesetaraan gender, diperlukan affirmative action bagi perempuan. Dalam budaya dan praktek politik yang sangat patriakis, tanpa penerapan kebijakan afirmatif, maka pemilihan umum hanya akan melanggengkan dominasi laki-laki di arena politik. Telah terbukti jika jumlah perwakilan perempuan di arena politik dan dalam proses pengambilan keputusan, maka perempuan bisa membuat perbedaan dan mereka bisa mempengaruhi keputusan atau kebijakan yang diambil.

Dalam perjalanan sejarah, Pemilu 2004 merupakan tonggak peningkatan keterwakilan perempuan di lembaga legislatif. Peningkatan tersebut memang sangat kecil dibandingkan dengan perjuangan para aktivis perempuan sejak proses Rancangan UndangUndang sampai Undang-Undang Pemilu 2003 yang mencantumkan kuota perempuan $30 \%$, tetapi patut disyukuri karena memang mengubah paradigma berpikir yang patriarkis menjadi cara berpikir kesetaraan gender membutuhkan waktu yang relatif lama.

Kebijakan kuota semestinya ditujukan untuk meningkatkan baik kesetaraan kesempatan (equality of opportunity) maupun kesetaraan menikmati (equality of result). Kesetaraan menikmati hasil merujuk pada angka perempuan di parlemen sementara kesempatan merujuk pada kemampuan untuk terlibat dalam pengambilan keputusan. Penekanan pada angka akan berimbas pada sempitnya fokus kebijakan yakni pada kehadiran semata, yang juga berarti menyingkirkan politik ide (the politics of idea) yang menekankan pada kebutuhan untuk menggunakan perspektif gender sebagai alat untuk menganalisis representasi perempuan. Oleh karena itu dapat dikatakan bahwa kebijakan kuota perempuan di Indonesia masih terjebak dalam pendekatan formalis dan belum menyentuh berbagai aspek yang bukan sekedar angka, melainkan pemberdayaan.

\section{PENUTUP/KESIMPULAN}

Keterlibatan perempuan dalam politik dari waktu ke waktu terus mengalami peningkatan. Salah satu indikatornya adalah tren peningkatan keterwakilan perempuan di legislatif- terutama sejak pemilihan umum (Pemilu) 1999 hingga Pemilu terakhir pada 2009. Pada Pemilu 1999 (9\%),Pemilu 2004 (11,8\%), dan Pemilu 2009 (18\%).

Peningkatan keterwakilan perempuan dalam politik, terutama dalam Pemilu, tersebut tidak terjadi secara serta merta, namun karena perjuangan yang terus menerus untuk mewujudkan hak setiap orang untuk mencapai persamaan dan keadilan. salah satunya adalah dengan mewujudkan peraturan perundang-undangan yang memiliki keberpihakan dan afirmatif terhadap peningkatan keterwakilan perempuan.

Ratifikasi Indonesia telah lama mengesahkan Undang-Undang (UU) No. 68 Tahun 1958 tentang Konvensi Hak Politik Perempuan. Di dalamnya, mengatur mengenai Perwujudan Kesamaan Kedudukan (non diskriminasi), jaminan persamaan hak memilih dan dipilih, jaminan partisipasi dalam perumusan kebijakan, kesempatan menempati posisi jabatan birokrasi, dan jaminan partisipasi dalam organisasi sosial politik. Namun, peningkatan keterwakilan perempuan terjadi setelah berlakunya perubahan Undaang- Undang Dasar (UUD) Negara Republik Indonesia Tahun 1945 yaitu pasal $28 \mathrm{H}$ ayat (2) yang menyatakan "Setiap orang berhak mendapatkan kemudahan dan perlakuan khusus untuk memperoleh kesempatan dan manfaat yang sama guna mencapai persamaan dan keadilan".

Ketentuan UUD 1945 tersebut menjadi landasan yang kuat bagi semua golongan warga negara untuk bebas dari diskriminasi sistematik dan struktural dalam 
berbagai aspek kehidupan, termasuk pada aspek politik. Karena itu, UU paket politik yang digunakan sebagai landasan pelaksanaan Pemilu 2004 maupun Pemilu 2009 mengakomodasi norma-norma hukum yang bertujuan untuk meningkatkan keterwakilan perempuan di legislatif.

Peningkatan keterwakilan perempuan di DPR harus disertai dengan pengawalan dan perjuangan yang berpespektif gender yang berkelanjutan di dalam proses politik. Karena itu, Partai Demokrat dan fraksinya di DPR perlu memiliki strategi untuk mempertahankan dan terus meningkatkan kualitas maupun kuantitas keterwakilan perempuan di lembaga legislatif.

Salah satu strategi yang dapat dilakukan oleh Fraksi Demokrat adalah dengan mendorong dan tetap mempertahankan penerapan affirmative action dengan kuota 30\% keterwakilan perempuan pada ranah politik, baik dalam kepengurusan partai politik maupun dalam penetapan bakal calon legislatif. Di samping itu, meski penetapan anggota DPR sama dengan DPD,- dalam arti dengan suara terbanyak, affirmative action yang ditindaklanjuti dengan kebijakan zipper system tetap harus dipertahankan.

Mahkamah Konstitusi (MK) telah memutuskan bahwa anggota DPR ditetapkan berdasarkan perolehan suara terbanyak bakal calon pada masing-masing partai politik yang memperoleh kursi DPR. Namun, MK tidak membatalkan dan tidak mempermasalahkan affirmative action kuota $30 \%$ dan zipper system 1 (satu) di antara 3 (tiga) keterwakilan perempuan dalam penetapan bakal calon anggota legislatif oleh partai politik.

Dengan demikian, Rancangan Undang-Undang (RUU) maupun UU paket politik yang akan dipergunakan sebagai landasan hukum pelaksanaan Pemilu 2014 tetap harus menerapkan affirmative action terhadap keterwakilan perempuan. UU Perubahan tentang Partai Politik, RUU Penyelenggara Pemilu, dan RUU Pemilu
Anggota DPR, DPD, dan DPRD, tidak boleh mengubah ketentuan yang sudah ada, meski dengan alasan keterpilihan seseorang sebagai anggota legislatif tergantung kepada pilihan langsung masyarakat.

Perubahan dan pembahasan RUU paket politik tersebut, tentu saja tetap memerlukan pengawasan dan pemantauan agar keterwakilan perempuan tetap terjamin. Selanjutnya, tinggal kesiapan perempuan sendiri dalam mencapai tujuan yang dicitacitakan bersama tersebut.

Dalam perspektif siyasah syar'iyah tentang keterwakilan perempuan dalam partai politik dilihat dari kedudukan perempuan dalam fiqh sisyasah merupakan agenda tersendiri dan penting untuk dilihat. Persoalannya tidak sekedar mempertanyakan kembali boleh dan tidaknya perempuan menjadi imam (pemimpin), tetapi bagaimana konsepsi fiqh dalam memandang peran politik perempuan secara umum. Secara garis besar, dalam membicarakan keberadaan hak-hak kaum perempuan berpolitik terdapat pendapat liberal-progresif yang membolehkannya perempuan berpolitik dan secara kontekstualpun dapat disimpulkan bahwa kaum perempuan juga berhak menjadi pemimpin sebagaimana kaum laki-laki.

Strategi yang dibutuhkan untuk menpersiapkan perempuan sebagai anggota DPRD dapat diawali dengan keseriusan parpol dalam memfasilitasi dan mempersiapkan perempuan untuk tampil di arena politik dan peningkatan pendidikan politik perempuan pada masyarakat. Parpol harus menyempurnakan skema atau pola rekrutmen kader perempuan secara berkelanjutan, melakukan advokasi, serta mengembangkan program pelatihan dan pendidikan politik yang dibutuhkan perempuan untuk mampu memainkan peranan yang penting.

Kebijakan pemerintah tentang kuota perempuan dalam partai politik dilihat dari keterlibatan perempuan dalam politik dan pemerintahan merupakan suatu anugerah 
Jurnal Sosial Humaniora Sigli (JSH)

p ISSN : 2615-3688

$e$ ISSN : 2716-0270

http://journal.unigha.ac.id/index.php/JSH

bagi keberlanjutan suatu negara. Maka dapat dipastikan bahwasanya perempuan memiliki andil yang luar biasa dalam mengatur kehidupan berbangsa dan bernegara.

\section{Daftar Pustaka}

Abdulkadir Muhammad. (2004) Hukum dan Penelitian Hukum, Bandung: Citra Aditya Bakti.

Abu Nash Al Faraby. (2004) As Siyasah Al Madaniyah, tahqiq dan syarah 'Ali Bu Milham, Beirut: Dar Maktabah Al Hilal.

Abdul Wahab Khallaf. (2003) Ilmu Usul Fiqih. Jakarta: Rineka Cipta, 2003

Ahmad Zaki Yamani. (1997) Syariat Islam Yang Kekal dan Persoalan Masa Kini, Jakarta Selatan: Intermasa.

Anonim. (2010), Rendahnya Anggota Legislatif Daerah dalam Menyuarakan Persoalan Masyarakat, Kompas, Edisi 17 Maret 2010.

Djazuli. (2003) Fiqh Siyasah, Jakarta: Kencana Prenada Media Group, 2003.

Fatimah Umar Nasif. (2001), Hak dan Kewajiban Perempuan dalam Islam, Terj. Burhan Wirasubrata, Jakarta: Cendekia Sentra Muslim.

Fitria, (2008) Peran Dukungan Orang Tua Dan Teman Sebaya Terhadap
Motivasi Belajar Siswa SMP Negeri 1 Kampar, Yogyakarta: UII Yogyakarta.

Herianti. (2017) Pemerintahan Indonesia Dalam Persfektif Siyasah Syar'iyah, Jurnal Aqidah-Ta Vol. III No. 2.

Ihromi. (2005) Kajian Wanita dalam Pembangunan, Jakarta: Yayasan Obor Indonesia.

Ikhwan Fauzi, Perempuan dan Kekuasaan,(Jakarta: Amzah, 2002)

Isnaeni. (2004), Peran Wanita dalam Politik, Jurnal Perempuan. Jakarta: Yayasan Jurnal Perempuan

Karam Azza dkk (2000). Perempuan di Parlemen. Jakarta: Yayasan Jurnal Perempuan

Liza Hadis dan Sri Wiyanti Eddyona, Pengakuan Peran Gender dalam Kebijakan-Kebijakan di Indonesia, (Jakarta: LBH Apik)

Muhammad, Anas Qasim Ja'far. (2001) Mengembalikan Hak-Hak Politik Perempuan Sebuah Perspektif Islam, Jakarta: Azan

Muhammad Iqbal dan Amin Husein Nasution (2010) Pemikiran Politik Islam; Dari Masa Klasik Hingga Indonesia Kontemporer, Jakarta: Kencana Pranada Group. 